\title{
Obstetric violence and medical education: answering "Who Is Afraid of Obstetric Violence?"
}

\section{Dear editor,}

Katz et al., 1 describe the importance of practical and conceptual definitions regarding obstetric violence. As cited in the article, obstetric violence is "any action or omission directed to women during prenatal care, labor or postpartum period, which can cause pain, harm or unnecessary suffering, that is performed without explicit consent or in disrespect to the patients' autonomy".2 Therefore, obstetric violence can also be considered gender violence, in which health practices and medical or professional knowledge outpace women's autonomy regarding her own self-knowledge. ${ }^{3}$ The authors also reflect upon the societies' and professionals' recognition of this term in order to enable eradication of obstetric violence. Conceptualizing the term "obstetric violence" raises awareness to the acts around us, and being able to identify them empowers people to fight against them.

Although disrespectful or harmful acts against pregnant women or during labor are thoroughly observed and described in medical offices or hospital environments, 4 this subject is less debated in the academic and formative fields. Therefore, it is impossible to confront obstetric violence without reforming health professional education. Among the necessary formative changes, we highlight the humanization of care, from medical graduate student education to professional practice activities. The subject of obstetric violence has to be debated in Universities and Health Schools as part of the curriculum. Furthermore, cognitive, interpersonal and intrapersonal skills, as well as personal virtues and values, such as positive communication, altruism and emotional intelligence, should be reinforced, considering that the doctor-patient relationship goes beyond technical skills and should be based on ethical communication, empathy and respect to one's autonomy. 5

Violent practice begins, for instance, with a poor doctor-patient relationship, between a person which owns the decision-making power legitimized by knowledge, and another, that is minimized by unfamiliarity and ignorance in the matter. ${ }^{6}$ Thus, many women are placed as passive during labor, and the professionals detain the position of authority, which establishes a verticalized and depersonalized relationship, ${ }^{3}$ despite the Ministry of Health's "guidelines for intrapartum care and positive child birth practices". Also, patients that are less inquisitive, tend to be better accepted by professionals, enabling a good relationship with the health team and demanding less assistance. On the other hand, when the patient questions or contests medical authority, or refuses to follow institutional routines, these acts are considered inconvenient. In this setting, the health practitioner may find it difficult to respect the patients' autonomy. ${ }^{6}$ Therefore, matters related to the doctor-patient relationship should be tackled since the very beginning of the professional formative process.

To date, the majority of medical education curriculums are based on Evidence Based Medicine, and do not equilibrate the four great pillars that should guide practice and clinical decisions: scientific knowledge, clinical experience, available resources and patient preferences. 7 Thus, at Health 
Education Institutions, there seems to be a sovereignty of "scientific knowledge" and "clinical experience" over women, their desires, bodies and beliefs. In order to change this scenario, humanization of the professional relationship between health professionals, patients and health institutions should take place, with profound transformations in professional training, respect and open-mindedness to new concepts; improvement in communication skills between the professional team and patients; to reconsider the excessively biologic model of medicine, and the adoption of greater political and ideological responsibility by health managers. ${ }^{7}$ In order to surpass fear, it is necessary to transform professional education and the relationships established in the context of our health system. It is important to undo the scenario of violence related to women health assistance in the practical performance fields, so that it does not become common practice ignored by future professionals.

\section{Author's contribution}

Klering NM, Petry LR e Garzella H: conception of the article, review of the literature and writing of the draft. Ogliari KS: supervision of writing, translation into English and final revision of the manuscript. Scherer JN: supervision of writing and final review of the manuscript. All authors approved the final version of the article.
Nathalia M. Klering 1

iD https://orcid.org/0000-0002-9337-740X

Laura R. Petry 2

iD https://orcid.org/0000-0001-8652-657X

Henrique Garzella 3

iD https://orcid.org/0000-0002-9553-2872

Karolyn Sassi Ogliari 4

(iD)

https://orcid.org/0000-0002-5902-6649
Juliana N. Scherer 5

iD https://orcid.org/0000-0002-9235-0416

1-4 Medical Sciences School. Universidade do Vale do Rio dos Sinos. Av. Unisinos, 950. Cristo Rei. São Leopoldo, RS, Brazil. E-mail: nathaliaklering@gmail.com

5 Post graduate Program in Collective Health. Universidade do Vale do Rio dos Sinos. São Leopoldo, RS, Brazil.

\section{References}

1. Katz L, Amorim MM, Giordano JC, Bastos MH, Brilhante AVM. Who is afraid of obstetric violence?. Rev Bras Saúde Mater Infant. 2020; 20 (2): 623-6

2. Sesc FPA. Mulheres Brasileiras e Gênero nos Espaços Público e Privado [Internet]. Mulheres Brasileiras e Gênero nos Espaços Público e Privado. 2010 [cited 2019 Jan 9]. p 301. Available from: https://fpabramo.org.br/publicacoes/ wp-content/uploads/sites/5/2017/05/pesquisaintegra_0.pdf

3. Palma CC, Donelli TMS. Violência obstétrica em mulheres brasileiras. Psico. 2017; 48 (3): 216-30.

4. Simone Grilo Diniz, Heloisa de Oliveira Salgado, Halana Faria de Aguiar Andrezzo, Paula Galdino Cardin de Carvalho, Priscila Cavalcanti Albuquerque Carvalho,

Received on November 4, 2020

Final version presented on Jauary 6, 2021

Approved on February 1, 2021
Cláudia de Azevedo Aguiar, Denise Yoshie Niy. Abuse and disrespect in childbirth care as a public health issue in Brazil: Origins, definitions, impacts on maternal health, and proposals for its prevention. J Hum Growth Dev. 2015; 25 (3): $377-82$

5. Costa FD, Azevedo RCS. Empatia, relação médico-paciente e formação em medicina: um olhar qualitativo. Rev Bras Educ Med. 2010; 34 (2): 261-9.

6. Sens MM, De Faria Stamm AMN. Physicians' perception of obstetric or institutional violence in the subtle dimension of the human and physician-patient relationship. Interface Commun Heal Educ. 2019; 23: 1-16.

7. Barros de Souza A, Da Silva LC, Das Neves Alves R, Jacinto Alarcão AC. Fatores associados à ocorrência de violência obstétrica institucional: uma revisão integrativa da literatura. Rev Ciênc Méd. 2017; 25 (3): 115-28. 